\title{
The Public Perception on Knowledge of Islamic Unit Trust in Malaysia
}

\author{
Ruqayyah Abdul Aziz \\ Rusni Hassan \\ Institute of Islamic Banking and Finance \\ International Islamic University Malaysia \\ Syed Ahmed Salman \\ Faculty of Business and Accountancy \\ Lincoln University College \\ Wisma Lincoln \\ No.12-18, Jalan SS6/12 \\ Off Jalan Perbandaran \\ 47301 Petaling Jaya, Selangor \\ Malaysia
}

\begin{abstract}
This paper sought to identify the public perception of Islamic unit trust fund in Malaysia from the perspective of investors and non-investors. Three aspects had been analysed i.e. (i) general knowledge on Islamic unit trust fund; (ii) knowledge on fund manager; and (iii) knowledge on the regulatory body and stock screening. The method used in this paper was descriptive analysis. A total of 200 questionnaires were distributed through a simple random sampling. The findings indicated that the respondents were aware of the existence of Islamic unit trust fund, significantly opined on a contrast between conventional and Islamic unit trust fund. The respondents, however, only had an average understanding on the familiarity of investing in unit trust. The knowledge on fund manager was considered good as the awareness in selecting a skilful fund manager was high. On the other hand, the knowledge on the regulatory body and stock screening were adequate, with a slight misconception on the benchmark of stock screening adopted by the Securities Commission Malaysia (SC). This study contributed towards a better understanding of the public perception hence aiding relevant authorities to draw effective measures in encouraging people into investing in the Islamic unit trust fund.
\end{abstract}

Keywords: Islamic Unit Trust Fund, Fund Manager, Regulatory Body, Stock Screening

\subsection{Introduction}

Mutual fund is one of the segments in capital market and it has been tremendously growing since decades. It is generally known in Malaysia as unit trust factually because the ownership is divided into units of entitlement (Taib \& Isa, 2007). Basically, unit trust is defined as an investment scheme by way of collective pool of funds invested by individuals, who share the same investment and financial objectives, and is managed and operated by qualified fund manager. Unit trust is considered as one of the most common investment vehicles to generate capital among investors and Muslims in particular, would choose Islamic unit trust fund for their investment since it is not contravening with Islamic principles. Islamic unit trust funds differ from the conventional funds in the sense that these funds are invested in a portfolio of Shariah approved financial assets such as Shariah-approved equities, Islamic bonds (Sukuk), Islamic deposits and Islamic money market instruments (AAOIFI, 2010).

Initially, Malaysia's development of unit trust industry was pioneered by British investors in 1959 with a company called Malayan Unit Trust Limited (Voonet al., 2012) and in 1960s and 1970s, the sector was led by two players i.e. Amanah Saham Mara Unit Trust Management and Asia Unit Trusts Berhad both owned by Majlis Amanah Rakyat Malaysia (MARA) (Saad et al., 2010). The first Islamic unit trust funds had been introduced in the mid-nineties through the establishment of Tabung Amanah Bakti (BaktiAmanah Fund) launched in May 1971 and managed by Asia Unit Trust Berhad, due to the growing demand from Muslim investors. As of today, there are 198 Islamic-based launched funds (Securities Commission Malaysia, 2016). 
Practically, Islamic capital market is driven by permitted economic and commerce activity following the principles outlined by the Quranic revelation and the practices of the Prophet Muhammad P.B.U.H. and his Companions. The fundamental features are the prohibition of Riba (interest), Gharar (uncertainty) and Maysir (gambling). Besides that, the practice is in line with the Shariah principles and some examples of contracts used in Islamic finance are Murabahah, Mudharabah, Musyarakah, Istisna', Wakalah and etc. Essentially, the whole purpose of the system is aimed to meet the Maqasid (objectives) of Shariah. One of the Maqasid in Islamic economic system is the preservation of wealth. The concept as explained by Muslim jurists covers the encouragement of generating, accumulating, preserving and also distributing the wealth in a just and fair manner. Therefore, in Islamic unit trust fund investors have the opportunities to generate, accumulate and preserve their wealth with a Shariah-compliance investment.

The gap between Islamic unit trust fund and conventional fund is relatively high in Malaysia as recorded by SC in 2015. The net asset value (NAV) to market capitalization of Islamic mutual fund is only 2.88 percent in contrast to the outstanding conventional achievement of 18.34 percent (Amin, Rizal, \&Supinah, 2015). Moreover, as at 30th June 2016 the total net asset value (NAV) of Islamic unit trust fund is only RM 54.46 billion, whilst its counterpart is RM 295.02 billion. Reflecting on this situation, there is a need to conduct a study to understand the public perception or knowledge level of Islamic unit trust fund in Malaysia which indirectly influenced the penetration rate.

In July 2016, Securities Commission Malaysia (SC) has declared latest initiatives to 'enhance the competitiveness and improve efficiency' of the Malaysian unit trust industry. This shows that Malaysian government is trying to improve the current practices of the industry. Indeed, Malaysia has its own regulatory body to govern the activities in the capital market for the soundness and stability of the market. There are several guidelines related to Islamic unit trust, namely Guidelines on Unit Trust Funds, Prospectus Guidelines for Collective Investment Schemes and Guidelines on Sales Practices of Unlisted Capital Market Products (Securities Commission Malaysia, 2016).

There are many elements that can be discussed with regards to Islamic unit trust and essentially it is included in the Guidelines. However, this paper will only focus on the following features of Islamic unit trust, which are the general understanding, fund manager, regulatory body and stock screening. Thus, the objective of this research is to study the public perception hold by the public in Malaysia towards Islamic unit trust fund based on the mentioned features before.

\subsection{Distinctive Features of Islamic Unit Trust Fund}

This section reviews literature on distinctive features of Islamic unit trust fund as compared to conventional practices, and outline the Shariah principles applied in the management of Islamic fund. The following are among the main difference between Islamic and conventional unit trust fund.

\subsection{Prohibition of Riba, Gharar and Maysir}

There are three fundamental bans in any Islamic commercial (mu'amalat) activities; Riba, Gharar and Maysir. Firstly, the prohibition of ' riba' means anything which is interest-based is not allowed. Secondly, the prohibition of ' gharar' means the restrictions on uncertainty, risk and hazard. Next, the prohibition of 'maysir' is referring to the forbiddance of gambling and any business activities related to it. Additionally, some activities that are contrary to the Islamic customs are also banned. Certainly, investment of Islamic funds in stocks that relate to the above is considered unacceptable.

\subsection{Shari'ah Stock Screening Process}

Stock screening is one of the major features in Islamic unit trust fund. The process is to determine the classification of funds invested in is Shariah or non-Shariah compliant. Adam \& Bakar (2014) believed that Shariah screening process is carried out for stocks elimination measured to be unacceptable for investments activities based on several criteria. In its early days of Islamic finance, the screening process was not practiced, mainly due to the fact it was either the investments were completely compliant or the absence of issues on Shariah compliant as it only involves Muslims. Nevertheless, after the establishment of joint ventures or partnership (shirkah) in the Islamic commercial space between Muslim and non-Muslim partners in numerous business events, the Muslim partners need to ensure that the conduct or partnerships are compatible to Shariah principles (Bakar, 2010). Shariah screening is also conducted to eliminate any involvement with sinful elements which encompasses analytical judgment, thorough research, and a well-elaborated process and time (Popotte, 2010). The screening of stock could be either positive or negative (Obaidullah, 2009; Sefiani, 2009). Positive screening refers to the investment in companies that involve with providing basic necessities to the society. On the other hand, negative screening will screen the companies that have high concentration on unethical activities such animal exploitation and bad relationship with employees. 
Generally, the screening is focused on two main compartments: business activities and financial ratios. The business screen (or sometimes known as qualitative screen or sect oral screen) is being conducted to investigate the nature of the core business. Meanwhile, the financial ratios or quantitative screen is being carried out to check the revenue of the company whether they are free from prohibited income or they are involved with it but under the acceptable ratio that has been permitted by the Shariah scholar (Adam \& Bakar, 2014).

\subsection{Purification Process}

In Islamic unit trust funds, there is a purification process that is done in the form of Zakat and Sadaqah. The debates on what should be purified can be categorised into three views namely dividend, capital gain and assets or liabilities (AAOIFI, 2010). The purification process for Zakat is conducted differently between countries. For instance, the law in Singapore regulates that the purification is managed by the fund manager; hence the deduction is done before the distribution of the returns to the investors. Malaysia, on the other hand, exercises the concept wherein the purification is under the investors' responsibility and not the fund manager, therefore no deduction is made before the distribution of the returns (Salleh \& Zakaria, 2015).

\subsection{Data Collection}

The study involves a sample of 200 respondents of both investors and non-investors of Islamic unit trust funds in Malaysia. The number of sample is significant as suggested by Gorsuch (1983) stating at least 100 subjects need to be used whilst Comrey and Lee (1992) advised the following scale: very poor -50 , poor -100 , fair -200 , and good -300 (Pearson and Mundform 2010). Besides that, previous studies have discussed on perception, relatively the analysis were using the same range, for example Kodun Abiah \&Wabekwa (2012) study on the "People's Perception Towards Islamic Banking: A Field Work Study in Gombe Local Government Area, Nigeria" using a sample of 134 respondents, Abdullah et al. (2012) inquire on "Perception of Non-Muslim Customers Towards Islamic Banks in Malaysia" using 152 respondent, and Loo (2010) for his paper on "Attitudes and Perceptions Towards Islamic Banking among Muslims and Non-Muslim in Malaysia: Implications for Marketing to Baby Boomers and X-Generation” with a total of 200 respondents.

To achieve the objective of this research, the sampling technique applied is probability sampling recognised as simple random sampling. The simple random sample is developed through a subset of individuals (a sample) selected from a larger set (a population) and the selection is completely random and unplanned. By doing so, any individuals carry the same chance or probability of being picked during the sampling process and the subset of $k$ individuals has an equal chance to be selected for the sample (Yates, Starnes \& Moore, 2008).

The questionnaire is divided into four sections. Section A, B and C are dependent variables developed using the fivelevel Likert item of 'strongly disagree', 'disagree', 'neither agree nor disagree', 'agree' and 'strongly agree.' Section D, on the other hand, is comprised of general items in describing the demographic profile of the respondents namely gender, age, religion, education level, occupations, monthly income, investment status (i.e. whether they are investors or non-investors), percentage of saving willing to put in the investment, motivations for investing in Islamic unit trust and lastly the suggestions to enhance the acceptance level of Islamic unit trust fund in Malaysia. There are ten statements under Section A and five statements under Section C and D respectively. Section B includes the general knowledge on Islamic unit trust fund, whilst Section $\mathrm{C}$ involves the understanding and preferences over fund manager. Lastly, Section D takes into account the knowledge on regulatory body and stock screening process

\subsection{Analysis and Result}

\subsection{Demographic Profile}

A total of 200 questionnaires are distributed to general population residing in Malaysia via online survey method. The demographic information of the respondents shows $70.5 \%$ are female and $29.5 \%$ are male in which $99.5 \%$ are Muslim and only $0.5 \%$ is non-Muslim. It is indicated that most of the respondents are between the ages of 18 to 35 which contribute $81.0 \%$ of the total respondents and the rest can be divided into $36-45$ years $(9.5 \%), 46-55$ years $(6.0 \%)$ and above $56(3.5 \%)$.

In term of respondents' highest education level, $8.0 \%$ of the respondents have Sijil Pelajaran Malaysia (SPM) and 6.5\% are Diploma-holders. Interestingly, majority of the respondents have Bachelor's and Master's degree which can be represented by $49 \%$ and $26.5 \%$ accordingly. Whereas $8 \%$ of the respondents are PhD-holders with the rest $2 \%$ has other education type. With regards to the occupation, $35.0 \%$ work in education and training area, $27.5 \%$ are in business, banking and financial operations field, $9.5 \%$ of the respondents as office and administrative supports, $5.0 \%$ are healthcare practitioners and 3.0\% work in legal sector. On the other hand, $20 \%$ of them are working in other occupation area. Lastly, almost half of the respondents (48.5\%) have a monthly salary of RM 2,499 and below. The rest receives wages between RM 2,500 to RM 4,999 (30.5\%), RM5, 000 to RM 9,999 (15.0\%) and RM 10,000 and above (6.0\%). 
In conclusion, the feedback received is mostly from Muslim (only $0.5 \%$ is non-Muslim) with majority of the respondents aged 35 and below. It is justified as the distribution of the questionnaire was done completely via online method and basically this age group is known to be more exposed to information technology (IT) or tech savvy compared to the other age groups. It is also observed the competency of respondents in answering this survey to be high considering at their education levels and in fact, is majorly categorized as professional in term of occupations. Table 1 show a demographic profile presented in percentage table as follow:

Table 1 Respondents' Demographic Profile

\begin{tabular}{|c|c|c|c|}
\hline Variables & Percentage (\%) & Variables & $\begin{array}{l}\text { Percentage } \\
(\%)\end{array}$ \\
\hline $\begin{array}{l}\text { Gender } \\
\text { Male } \\
\text { Female }\end{array}$ & $\begin{array}{l}29.5 \\
70.5\end{array}$ & $\begin{array}{l}\text { Education } \\
\text { Sijil Pelajaran Malaysia (SPM) } \\
\text { Diploma } \\
\text { Bachelor's Degree } \\
\text { Master's Degree } \\
\text { Doctor of Philosophy } \\
\text { Other }\end{array}$ & $\begin{array}{l}8.0 \\
6.5 \\
49.0 \\
26.5 \\
8.0 \\
2.0\end{array}$ \\
\hline $\begin{array}{l}\text { Age } \\
18-25 \text { years } \\
26-35 \text { years } \\
36-45 \text { years } \\
46-55 \text { years } \\
56 \text { and above }\end{array}$ & $\begin{array}{l}25.0 \\
56.0 \\
9.5 \\
6.0 \\
3.5\end{array}$ & $\begin{array}{l}\text { Occupation } \\
\text { Education \& Training } \\
\text { Business, Banking \& } \quad \text { Financial } \\
\text { Operations } \\
\text { Healthcare Practitioners } \\
\text { Legal } \\
\text { Office \& Administrative Support } \\
\text { Others }\end{array}$ & $\begin{array}{l}35.0 \\
27.5 \\
5.0 \\
3.0 \\
9.5 \\
20.0\end{array}$ \\
\hline $\begin{array}{l}\text { Religion } \\
\text { Muslim } \\
\text { Non-Muslim }\end{array}$ & $\begin{array}{l}99.5 \\
0.5\end{array}$ & $\begin{array}{l}\text { Monthly Income } \\
\text { RM 2,499 and below } \\
\text { RM 2,500 - RM 4,999 } \\
\text { RM 5,000 - RM 9,999 } \\
\text { RM 10,000 and above }\end{array}$ & $\begin{array}{l}48.5 \\
30.5 \\
15.0 \\
6.0 \\
\end{array}$ \\
\hline
\end{tabular}

\subsection{General Knowledge on Islamic Unit Trust Fund}

For this aspect, the discussion is divided into two; (i) Statement 1 to 4, and (ii) Statement 5 to 10 . The former is identified as basic questions on the Islamic unit trust investment and the latter comprises of element of religion and certain Shariah values. Statement 1 to 4: As shown in Figure 1, the number of respondents who are familiar in unit trust fund investment is almost equal to the number of respondent that are unfamiliar with it. $28.5 \%$ of the respondents agree that they are knowledgeable in the investment of the unit trust fund whilst $29.5 \%$ do not know about it and the rest $(42 \%)$ hold a neutral view (S1). Interestingly, most of the respondents $(70 \%)$ have heard about Islamic unit trust fund before (S2) yet only 39.5\% understand the concept of Islamic unit trust fund (S3). Nonetheless, 12\% of the respondents have never heard about Islamic unit trust fund and 3.5\% opines that there is no difference between conventional and Islamic unit trust fund whilst majority of them (81\%) agree on the dissimilarity (S4). It can be concluded from this paragraph, though the respondents' knowledge on Islamic unit trust fund investment are only on average level, the existence of it is known to them knowing there is a contrast between conventional and Islamic fund.

Statement 5 to 10: It is presented in Figure 2, majority of the respondents $(81.5 \%)$ know that Islamic unit trust can be subscribed by both Muslims and non-Muslims (S5) and up to $83 \%$ believe investing in it does not conflict with their religious beliefs (S6). On the other hand, 6\% of the respondents say the Islamic unit trust fund investment is limited to Muslims. These statements are related as it is a fact the investment is open to anyone regardless of religion, hence no conflicting issue of beliefs. Next, $74 \%$ of the respondents agree on the involvement of profit sharing and loss bearing principles in Islamic unit trust (S7). 6\% of the total respondents however, get the wrong idea that there is interest reward system in it (S8). The management of Islamic fund basically adopts Shariah principles in it and as outlined by the Guidelines of Islamic Fund Management by the Securities Commission Malaysia (SC), there are 14 principles used. One of it is profit sharing and loss bearing (Mudharabah). Following that, $72 \%$ of the respondents know that Riba (interest), Gharar (uncertainty) and Maysir (gambling) are the main elements in determining the Shariah-compliant of the investment (S9). Thus, by implying there is an interest reward system in the investment is totally unfitting. 
Most of the respondents (88\%) are on the agreement that it should not involve in prohibited activities as agreed by Islam such as conventional banking and insurance, liquor and liquor-related activities and non-halal food and beverages (S10). This is factual because Qur'an, the Holy Book for Muslim, indeed has mentioned about it in the verse.
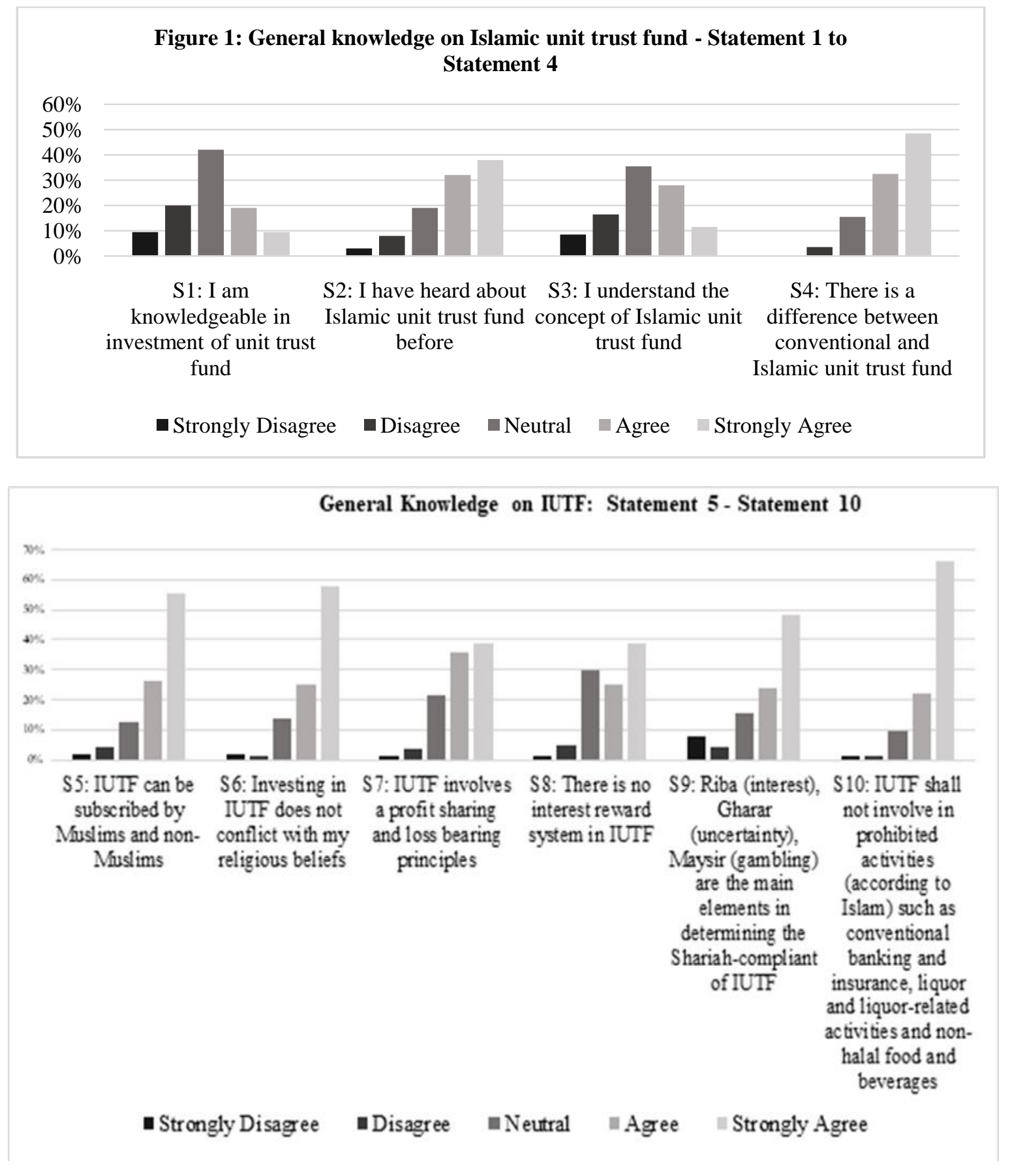

\subsection{Knowledge on Fund Manager}

With regards to the knowledge on fund manager the respondents were asked on few aspects on the fund manager being one of the factors that motivate the investor to subscribe to the Islamic unit trust. 


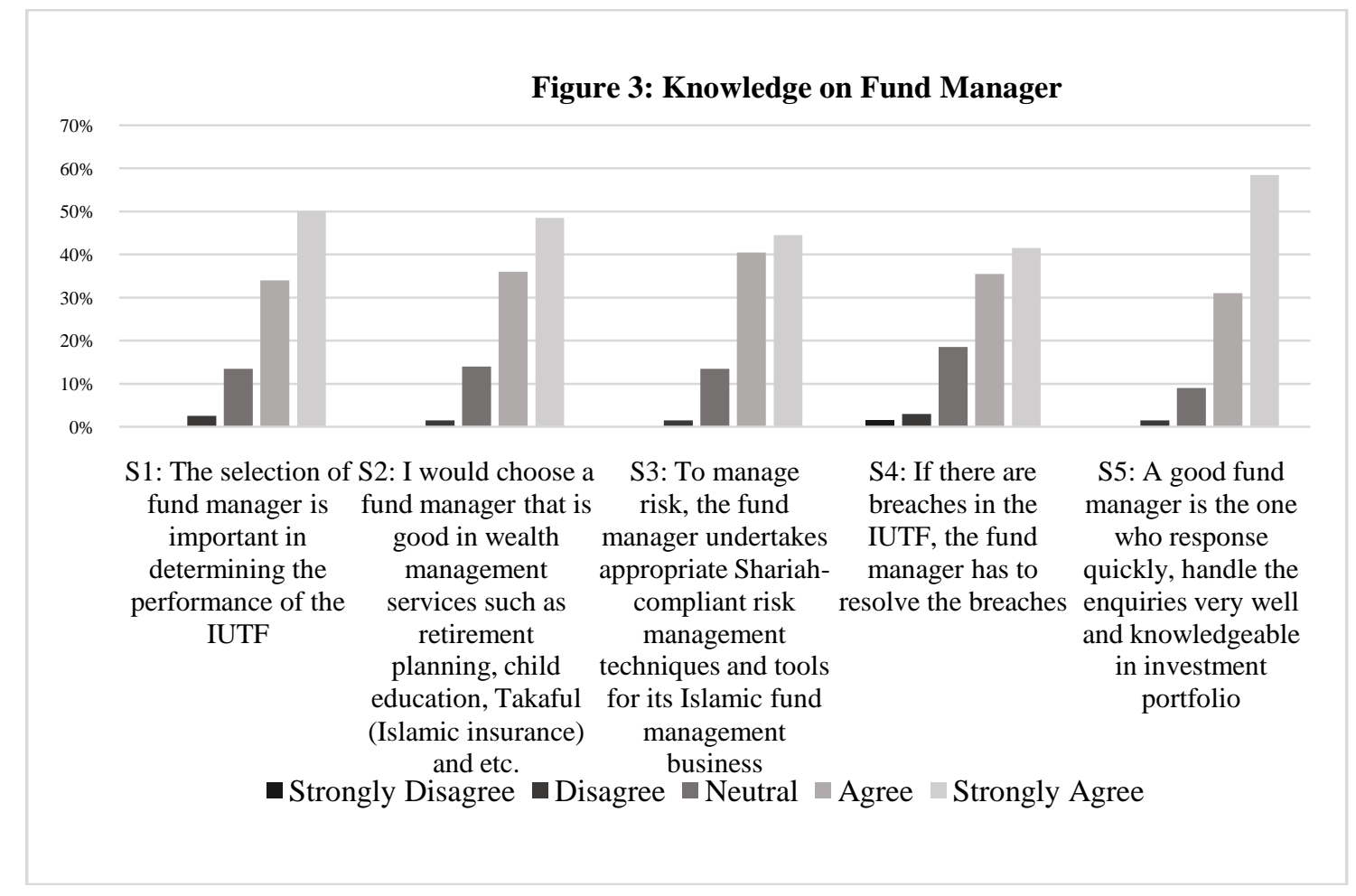

As depicted in Figure 3, most of the respondents $(84 \%)$ consider the selection of fund manager in determining the performance of the fund as fundamental (S1) and $84.5 \%$ of them would choose ones that are good in wealth management services like retirement planning, child education, takaful and others (S2). Besides that, 85\% of the respondents believe it is the responsibility of fund manager to undertake appropriate Shariah-compliant techniques and tools in managing the risk for the Islamic fund management business (S3). Further, 77\% of the total respondents agree that the fund manager has to resolve any breaches in the Islamic unit trust funds (S4). In general, almost $90 \%$ say a response quickly and handles the enquiries very well plus knowledgeable enough in investment portfolio and merely less than 5\% are contradicting with all the statements mentioned above (S5).

Generally, the survey shows that the knowledge of respondents on the fund manager is considered adequate as the awareness is high in selecting a skilful fund manager to handle the investment and to perform accurate Shariahcompliant risk management techniques. The behaviour of the respondents indicates that the fund manager has effectively performed their jobs in general.

\subsection{Knowledge on Regulatory Body and Stock Screening}

The respondents were also asked on their knowledge on the regulatory aspects of Islamic unit trust such as the regulatory authority, the Shariah Advisory Council, the Shariah Adviser and the regulatory requirement on the stock screening. The result is shown in Figure 4. 


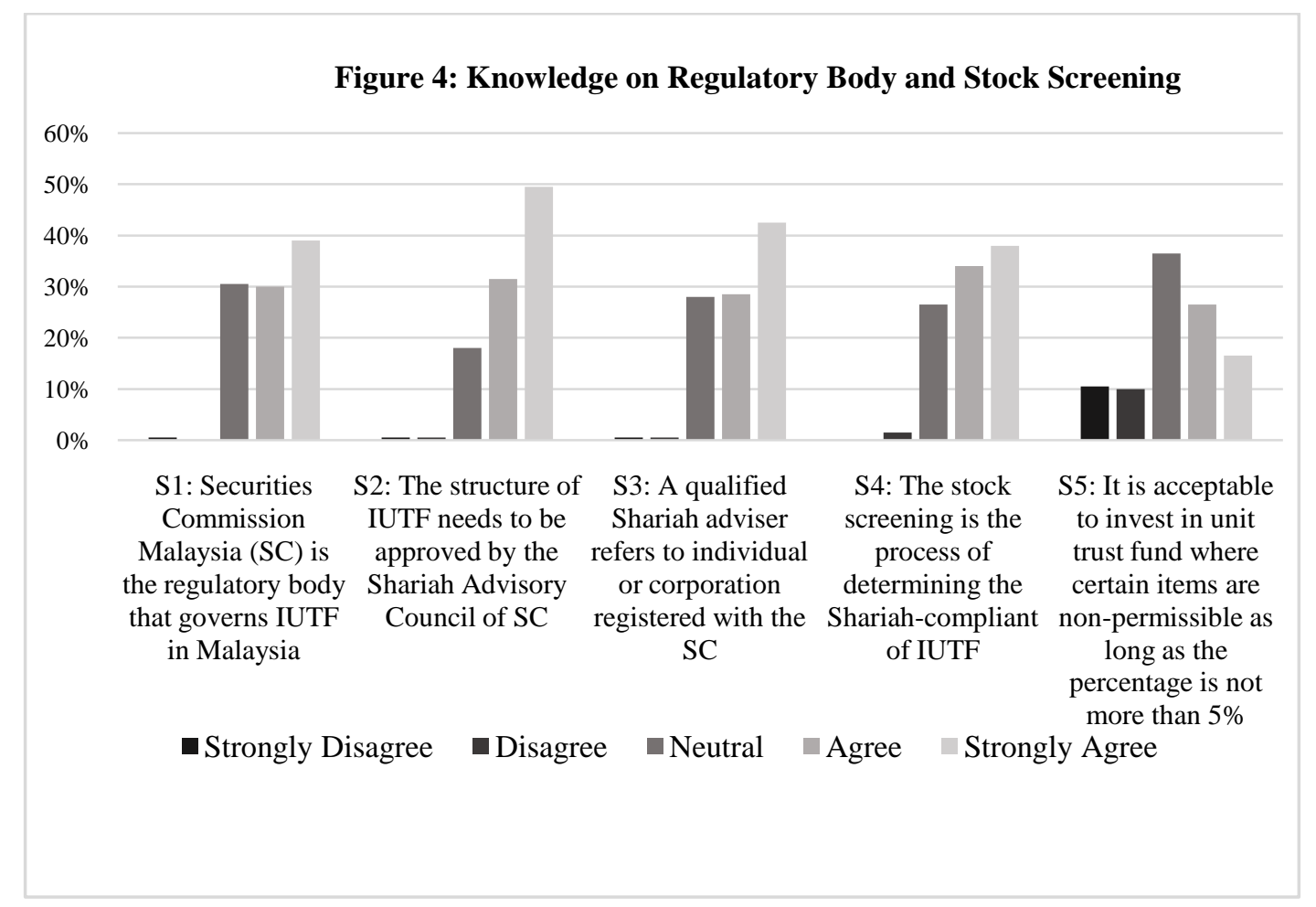

$69 \%$ of the respondents know Securities Commission Malaysia (SC) is the regulatory body that governs the industry in Malaysia (S1). SC is acclaimed to be a statutory body established in 1993 with countless regulatory functions. These include managing central depositories, houses clearance, and exchanges, corporate bond issues on authority approval, licensing and overseeing all licensed persons and regulating all matters associated with unit trust schemes (Securities Commission Malaysia, 2016).

As shown in the figure above, $81 \%$ of them agree Islamic unit trust structure required an approval by the Shariah Advisory Council (SAC) of SC (S2). This shows an indirect awareness of respondents towards the establishment of the Council. SAC indeed is a special committee initiated by the Commission for the purpose of giving advices on Shariah matters relating to Islamic capital market in Malaysia.

In addition, $71 \%$ of the respondents recognise a qualified Shariah adviser is referring to individuals or corporation registered with the SC (S3). According to the SC's Guideline on Islamic Fund Management, the duties of the Shariah adviser are to provide advices by following the principles of Shariah for Islamic fund management business, to review reports that the investment activities are Shariah-compliant and to prepare a periodic report of the Islamic fund management business for the confirmation and certification that it has been managed and administered accordingly.

For the knowledge on stock screening, $72 \%$ of the respondents are alert with the process to know whether the funds are Shariah-compliant or not (S4). However, only 43\% of them know that it is acceptable in accordance to the SC's guidelines to invest in funds where certain items are non-permissible as long as the percentage is not more than 5\% (S5). 20.5\% of the total respondents opine on the unacceptable for such benchmark of Islamic funds investment.

It is observed that the knowledge on regulatory body and stock screening amongst respondents are on satisfactory level. Nevertheless, there is still misapprehension on the benchmark of stock screening indicating the needs for regulators to ensure the delivery of information is done comprehensively.

\subsection{Conclusion}

After observing on the general knowledge, the researcher concludes that the respondents were aware of the existence of Islamic unit trust fund, knowing there was a contrast between conventional and Islamic fund, though the familiarity with the investment in unit trust was only on average level. The knowledge on fund manager was considered good as the awareness in selecting a skilful fund manager was high. The knowledge on the regulatory body and stock screening basically were satisfactory, with a slight misconception on the benchmark of stock screening adopted by the Securities Commission Malaysia (SC). The implication of this paper towards investor is indeed useful. First and foremost, after analysing the level of knowledge in general, investors are able to measure their own knowledge on the topic discussed as the statements developed in this survey are actually combination of several Guidelines provided by the Securities Commission Malaysia (SC). 
For Islamic fund companies, this study allows them to grab the idea of public perceptions toward the investment in Islamic unit trust fund. It can be observed the awareness on investing in Islamic unit trust is still low hence indicating opportunities available for the management companies to attract prospective investors through conducting regular programs, seminars, workshop or training about unit trust investment to educate them. Fund manager, knowing that not all of the investors understand fully the concept, Shariah principles applied, stock screening process and regulatory body related to Islamic unit trust, should give clear information about it. In the perspective of regulator, this research helps them to identify the weaknesses in informing the public comprehensively and thoroughly about the Islamic unit trust investment. Some components especially stock screening (limited to the topic researched) need to be informed to the public in order to avoid misunderstanding on the benchmark applied. Besides that, regulator can also reach the public by cooperating together with the fund management companies in providing the seminars, talks and workshops to increase the awareness level.

\subsection{References}

Abdullah, A. A., Sidek, R., \& Adnan, A. A. (2012). Perception of Non-Muslims Customers towards Islamic Banks in Malaysia. International Journal of Business and Social Science Vol. 3 No. 11, 151-163.

Accounting and Auditing Organization for Islamic Financial Institutions (AAOIFI). (2010). Sharia Standard. Bahrain: AAOIFI.

Adam, N. L., \& Bakar, N. A. (2014, September). Shariah Screening Process in Malaysia. Procedia Social and Behavioral Sciences, p. 121.

Amin, H., Rizal, H., \& Supinah, R. (2015). What Makes Investors Invest in Islamic Mutual Funds? Labuan Bulletin of International Business \& Finance Vol. 13, 31-48.

Bakar, M. D. (2010). Jurisprudence of Screening in Contemporary Islamic Finance Architecture. Dow Jones Islamic Market Indexes Newsletter.

Comrey, A. L., \& Lee, H. B. (1992). A first course in factor analysis (2nd edn). New Jersey: Lawrence Erlbaum Associates.

Gorsuch, R. L. (1983). Factor analysis (2nd edn). New Jersey: Erlbaum.

Kodun Abiah, F., \&Wabekwa, B. (2012). People's Perception towards Islamic Banking: A Field Work Study in Gombe Local Government Area, Nigeria. International Journal of Business, Humanities and TechnologyVol. 2 No. 7, 121-131.

Loo, M. (2010). Attitudes and Perceptions towards Islamic Banking among Muslims and Non Muslims in Malaysia: Implications for Marketing to Baby Boomers and X-Generation.International Journal of Arts and Sciences, 453-485.

Saad, N. M., Abd. Majid, M. S., Kassim, S., Hamid, Z., \&Mohd. Yusof, R. (2010). A Comparative Analysis of the Performance of Conventional and Islamic Unit Trust Companies in Malaysia. International Journal ofManagerial Finance Vol. 6 Iss. 1, 24-47.

Taib, F. M., \& Isa, M. (2007). Malaysian unit trust aggregate performance. Managerial Finance Vol. 33 Iss. 2, 102121.

Obaidullah, M. (2009). Some Issues in Shari'ah Compliance and Regulation of Islamic Funds. J.KAU: Islamic Economics. Vol. 22. No.1.

Pearson, Robert H., and Daniel J. Mundform. (2010). Recommended Sample Size for Conducting Exploratory Factor Analysis on Dichotomous Data. $\quad$ Journal of Modern Applied Statistical Methods Vol. 9 Iss. 2 359368.

Popotte, M. (2010). Industry Snapshot: Opening the Black Box of Shariah Stock $\quad$ Screening. Retrieved from http://www.Opalesque.com/OIFIArticle/96/theBlack_Box_of_Shariah_Stock8 50.html.

Salleh, A. Z., \& Zakaria, M. Z. (2015). Purification of Islamic Unit Trust Funds: A Shariah Analysis on Malaysia Approach. Al-Qanatir International Journal of Islamic Studies Vol.2 No. 2.

Securities Commission Malaysia. (2016, August 16). Unit trust funds in Malaysia Summary of Statistics. Retrieved from Securities Commission Malaysia: http:// www.sc. com.my/data-statistics/unit-trust-fundsin-malaysia summary of statistics/

Sefiani, Z. (2009, July 31). New Generation of Shariah Stock Screening. Retrieved from Islamic $\quad$ Finance News: http://www.kantakji.com/fiqh/Files/Fatawa/es1.pdf

Voon Choong, Y., KokThim, C., Yong Gun Fie, D., \& Huang Ng, C. (1548). Development and Performance Trends of Malaysian Unit Trusts. Journal of Modern Accounting and Auditing, 8(12), 1804-1813.

Yates, D., Starnes, D. S., \& Moore, D. S. (2008). The Practice of Statistics. New York:W.H.Freeman \& Co Ltd. 